$$
\begin{gathered}
\text { 응급구조사의 성격유형이 직무관련 산출변수에 미치는 영향 } \\
\text { 박재성 } 1 \neq, \text { 김미숙 }{ }^{2} \\
{ }^{1} \text { 고신대학교 의료경영학과, }{ }^{2} \text { 춘해보건대학교 응급구조과 }
\end{gathered}
$$

\title{
Impacts of Emergency Medical Technicians' Personal Traits on Job Related Outcome Variables
}

\author{
Jae-sung Park ${ }^{1}$, Mi-sook Kim ${ }^{2}$ \\ 'Department of Health Care Administration, Kosin University, \\ ${ }^{2}$ Department of Emergency Medical Technology, Choonhae Colleage of Health Sciences
}

\begin{abstract}
$<$ Abstract $>$
The purpose of this study is to identify the effects of emergency medical technicians' personal traits and job characteristics on job/social stress, job satisfaction, role conflicts, organizational commitment, and self-efficacy.

The study population was emergency medical technicians who is working at the hospitals in Yeungnam province. The 200 questionnaires were administered by using ground mail, e-mail, and personal visits and 156 questionnaires were returned( $82.5 \%$ response rate).

Social stress, job satisfaction and role conflicts were significantly determined by personal traits and job characteristic variables. However, job stress, organizational commitment and self-efficacy was only significantly determined by job characteristic variables. In social stress and role conflicts, the subjects with challenge, sociability, acceptance and prudence traits were tend to be significantly higher scores compared to the stability traits. Additionally, among social stress regression models, adding job characteristics to the personal traits model, $\mathrm{R}^{2}$ was increased up to $19 \%$ and adding personal traits to the job characteristics model, $\mathrm{R}^{2}$ was increased up to $14 \%$.

In conclusion, the study found that personal traits and job characteristics are important variables in explaining social stress, job satisfaction and role conflicts, that would have important managerial implications for recruiting, hiring and managing either new or current emergency medical technicians efficiently.
\end{abstract}

Key Words : Personal Traits, Social Stress, Job Stress, Organizational Commitment, Role Conflicts

* 본 연구는 2011년 고신대학교 교내 연구비 지원에 의해 수행되었음 


\section{I . 서론}

응급의료체계(EMSS: Emergency Medical Services System)는 응급상황 발생 시 효과적이고 신속하게 의료를 제공하기 위해서 인력, 시설, 장 비를 유기적으로 운용할 수 있도록 하는 의료 사 회적 조직을 의미한다. 미국이나 유럽국가에서는 1960년대 이후 국가적 지원으로 응급환자를 위한 별도의 조직을 운영하였지만 우리나라는 1980년대 에 비로소 공공의 개념으로 응급환자 후송을 시작 하였다. 우리나라는 1994년 성수대교 붕괴, 1995년 삼풍백화점 사고 등 다양한 인재를 겪으면서 효율 적인 응급의료수행을 위한 조직체계의 필요성을 절실히 느끼면서 응급구조에 전문적인 지식과 경 험을 가진 인력을 양성을 요구하기 시작하게 되었 다[1].

1994년 응급의료에 관한 법률의 공포는 우리나 라 응급의료체계구축의 시발점이 되었고, 2000년대 에 들어서면서 비로소 선진국과 비슷한 있는 수준 에 도달하였다고 할 수 있다. 응급의료기관의 응급 실은 24 시간 응급환자를 진료할 수 있는 인력과 시설 및 장비를 갖추어야한다. 이외에도 구급차, 통신장비 등을 구비해야하고, 응급의료수행에 적합 한 구조로 설계되어 있어야 한다. 국가에서는 응급 실의 가용 자원이나 특수처치 이용 가능성에 따라 응급의료기관을 등급화하고 있으며, 응급의료기관 의 수준향상을 위해서 응급의학전문의 진료체계 완비, 응급실근무인력의 고급화, 시설, 장비의 선진 화를 위해 중장기 계획을 수립하여 매년 응급의료 기관을 평가하고 그 결과에 따라 재정지원을 하고 있다[1].

병원에서의 응급의료체계의 운용은 현장처치의 검토 및 연속적인 응급처치, 진단을 위한 적절한 검사, 입원치료 혹은 응급수술 결정, 환자의 응급 처치에 필수적인 의료진이나 시설, 장비가 준비된 전문응급센터나 응급의료기관으로 전원 여부의 결
정과 전원 병원 결정을 하여야하며, 병원단계 응급 의료 인력으로는 응급의학의사, 응급전문간호사가 필요하고, 병원 전 단계나 병원단계에서 제약 없이 근무할 수 있는 응급구조사가 있다[2].

1996년부터 배출되기 시작한 1급 응급구조사는 전문대학 3 년제 혹은 4년제 대학교를 졸업하고 보 건복지부장관이 실시하는 국가고시에 합격한 후 보건복지부장관의 자격인정을 받아야 한다. 응급구 조사의 응급의료센터 고용에 대해서는 아직 논란 의 여지가 있으며, 이는 업무의 성격이 간호 분야 와 유사한 점이 많아 마찰이 일어날 수 있기 때문 이다. 하지만 응급구조사의 교과과정이나 업무능력 으로 볼 때 응급의료센터 내에서 환자의 병원 간 이송, 의료전송 감시, 환자분류 등의 다양한 업무 에 투입될 수 있다. 다만 응급의료센터 고용은 응 급의료센터의 크기나, 지역적인 특성, 법적 뒷받침, 그리고 병원방침 등이 영향을 미칠 수 있지만 응 급의료법 제 41 조 규정에 의하여 의료기관안에서도 응급처치 업무에 종사할 수 있도록 되어 있으므로 응급구조사의 응급의료센터 고용에 대한 법적제한 은 없다. 그러므로 현재 우리나라의 경우 전문의 부족, 의료지도체계 미비, 외과의사 부재 등을 고 려해 볼 때 응급구조사의 역할이 매우 중요하다고 볼 수 있다[3].

응급구조사는 응급상황에서 외상이 있는 다수의 환자나 사망자에 대한 처치를 효과적으로 수행할 수 있는 전문성과 인내심이 필요하고, 또한 조직 내에서는 인간관계에서의 불만족이나 갈등, 스트레 스 등에도 잘 대처할 수 있는 능력이 필요하다고 할 수 있다. 따라서 응급구조사의 내재적인 특성인 성격과 직무 변수가 직무관련 산출 변수, 즉 직무 및 사회적 스트레스, 직무만족, 역할갈등, 조직몰입 그리고 자기효능감에 미치는 영향을 파악하는 것 은 보다 효과적인 응급의료체계의 운용에 있어 응 급구조사가 처한 문제를 파악하여 보다 효과적인 업무를 수행할 수 엤게 하는 것에 기여할 수 있을 
것이다.

근로자의 내재적 특성을 의미하는 성격유형에 대한 연구로서 이영균과 최인숙[4]과 이정선과 유 정이[5]은 성격유형에 따라 직무만족에 차이 있음 을 보고하였다. 따라서 인간의 일반적인 특성이라 할 수 있는 성격이 직무만족 이외의 다른 직무관 련 산출 변수에도 유의미한 영향력이 있는지 파악 하는 것이 필요하다고 할 수 있다. 이 연구에서는 직무관련 산출 변수를 참고문헌 고찰을 통하여 파 악하였다. 기존의 연구들에서 가장 보편적으로 사 용된 종속변수로는 직무 및 사회적 스트레스, 직무 만족, 역할갈등, 조직몰입 그리고 자기효능감이었 고, 이 연구에서는 이를 직무관련 산출 변수로 정 의하여 선택하였다. 또한 이전의 연구들은 이들 변 수를 개별적으로 연구한 한 반면 이 연구에서는 동일한 대상에서 6가지 직무관련 산출변수를 동시 에 연구함으로써 응급구조사에 대한 관리적 함의 를 종합적으로 도출하고자 한다.

직무관련 산출변수 중 스트레스 요인을 연구한 조희 등[6]은 스트레스 요인을 사회적 요인, 응급 상황, 조직관련, 과제특성으로 나누었고, 특히 사 회적 위기상황에서 느끼는 스트레스를 파악하였다. 일반적으로 사회적 스트레스는 사회적 지원이나 지지체계가 무너질 때 발생되는 것으로 정의할 수 있고, 조직에서 발생하는 가장 보편적인 대인관계 요인 중에서 고객들과의 관계 즉 환자나 보호자의 불신, 욕, 구타 등에서 발생하는 스트레스를 의미 한다[7]. Pierce와 Sanrasson[8]의 연구에서도 사회 적인 스트레스는 생물학적인 관점에서 스트레스와 달리 개인과 환경사이의 상호작용과 각 개인의 사 건과 경험에 대한 평가 시스템에 의해 결정되는 것으로 정의하였으며, 사회적 지지가 갈등과 스트 레스를 결정하는 중요한 요소임을 보고하였다. 역 할갈등과 관련된 연구로는 성미혜의 연구[9]에서 경력, 종교, 결혼유무에 따라 역할갈등의 차이가 있음을 보고하였다. 직무만족과 관련된 연구에서는
박상섭 등[10]이 응급구조사의 직무만족이 조직몰 입에 대한 영향력을 파악하였으며, 박재산과 이미 순[11]은 간호사의 직무만족과 이직의사의 관련성 을, 그리고 여진동과 고인호[12]는 방사선사를 중 심으로 연구하였다.

이 연구의 목적은 응급구조사의 내재적요인 성 격특성과 직무 특성이 응급구조 업무를 수행하는 과정에서 느낄 수 있는 업무관련 산출 변수 즉, 직 무 및 사회적 스트레스, 직무만족, 역할갈등, 조직 몰입 그리고 자기효능감에 미치는 영향을 파악하 고자 하였다. 이는 응급의료체계의 핵심적 요인인 응급구조사에 대한 보다 효과적인 운용과 조직관 리에 함의를 도출 하고자하였다.

\section{II. 연구방법}

\section{1. 자료 수집 방법}

본 연구는 문헌 고찰을 통하여 직무 및 사회적 스트레스, 직무만족, 역할갈등, 조직몰입 그리고 자 기효능감을 측정할 수 있는 설문을 개발하였다. 설 문 도구의 신뢰도와 타당도를 검정하기 위하여 두 차례의 예비조사를 거쳐 문제점을 보안하여 본 조 사를 하였다. 1 차 예비조사는 현재 재직 중인 응 급구조사 20명을 대상으로 하였으며, 2차 예비조사 15 명을 대상으로 하였다. 본 조사에는 2008년 대한 병원협회의 명부를 기준으로 영남지역에 위치한 병원에 현재 근무하고 있는 1 급 응급구조사 217명 을 대상으로 하였다. 설문지는 각 병원의 담당부서 의 연락처를 확보한 뒤 전화 및 공문 협조를 요청 하고, 총 200 부를 발송하여 165 부를 회수하였다. 응답률을 높이기 위해 각 병원 담당자와 지속적인 연락과 방문을 실시하였다. 응답자 중 응답이 부실 한 설문지 9부를 제외하고 156명을 분석대상으로 하였다. 설문 응답률은 $82.5 \%$ 였다. 
2. 통계분석

본 연구는 Cronbach's a를 이용하여 설문도구의 내적신뢰를 파악하였으며, 또한 구상타당도를 파악 하기 위하여 요인분석을 하였다. 성격 및 직무 변 수가 6가지 직무관련 산출변수에 미치는 영향력을 파악하기 위하여 회귀분석을 하였다. 마지막으로 각 회귀모형에서 성격 변수와 직무 변수의 존재 유무에 따른 회귀모형들의 개선 정도를 파악하기 위하여 부분적 분산분석(partial F-test)을 하였다.

\section{3. 변수의 조작적 정의}

본 연구 성격유형의 측정은 박제일 등[13]이 개 발한 대인관계특성검사, ITS(Interpersonal Trait Scale) 70 문항을 이용하여 측정하였다. 그 유형은 주장성, 친화성, 순응성, 치밀성, 정서적 안정성으 로 구성되었으며 그 정의는 <표 $1>$ 과 같다.

직무스트레스는 김매자와 구미옥[14]의 근무 중 발생되는 생리적, 심리적, 사회적인 장애를 받을 정도로 부담을 느끼는 상태로 정의하였으며, 김성 곤[15]이 개발한 도구 중 3 문항(Croonbach's a
.92)을 수정하여 이 연구에 사용하였다. 사회적 스 트레스는 환자와 보호자로부터 발생하는 스트레스 나 사회적 지원이나 지지 체계가 무너져 발생하는 스트레스로 정의하였다. 측정도구는 조희 등[6]이 개발한 스트레스 척도 중 사회적 요인 항목 중에 서 이 연구에 맞게 수정한 5문항(Croonbach's a .92)을 사용하였다. 직무만족은 조직내의 환경과 교 육, 후생복지에 대한 만족으로 정의하였으며, 김성 곤[15]의 측정도구를 수정하여 사용하였다 (Croonbach's a .90).

역할갈등은 House와 Risso[16]의 정의를 이용하 여 개인이 외부에서 요구하는 역할기대에 따라 행 동할 수 없는 것으로 지각된 역할로 하였으며, 측 정도구는 김영훈[17]의 7개 항목(Croonbach's a .92)을 수정하여 이용하였다. 조직몰입 측정도구는 서흥수[18]의 연구에서 사용한 도구(Croonbach's a .94)를 일부 수정하여 6문항으로 구성하였다. 자기 효능감 측정도구는 박재성[19]의 한 종합병원 구성 원의 경영목표 지향성의 구조적 모형과 선호 경영 성과지표에서 개발한 3문항(Croonbach's a .82)을 사용하였다.

<표 1> 성격유형의 조작적 정의

\begin{tabular}{|c|c|}
\hline 성격유형 & 특징 \\
\hline $\begin{array}{l}\text { (1) 도전성 } \\
\text { (challenge) }\end{array}$ & $\begin{array}{l}\text { - 자신의 의사를 거침없이 표현하며, 목표달성을 위해서 신속한 움직인다. } \\
\text { - 거침없이 진행하는 성향이 있고, 모험을 즐기는 강인한 속성이 있다. } \\
\text { - 자신의 주장을 강하게 제기하고, 리더가 되고자하는 성향을 보인다. } \\
\text { - 목표 달성을 위해 열정적이고 강인한 성향을 보인다. }\end{array}$ \\
\hline $\begin{array}{l}\text { (2) 사교성 } \\
\text { (sociability) }\end{array}$ & $\begin{array}{l}\text { - 항상 주위에 사람들이 함께하는 사교적인 속성이다. } \\
\text { - 낙천적이고 유머를 즐겨 사용하는 넉사ㄹㅗㅗㅎ은 행동은 낯선 타인과의 인간관계를 원활하게 하는 윤활유 같은 역할을 한다. } \\
\text { - 말이 많지만 표현력이 좋아 타인의 관심을 끌며, 매사에 꽁하지 않는 개방적인 성향을 보이고 있다. }\end{array}$ \\
\hline $\begin{array}{l}\text { (3) 수용성 } \\
\text { (acceptance) }\end{array}$ & $\begin{array}{l}\text { - 친절하고 다정다감하며, 타인을 배려하는 속성 때문에 양보와 헌신적인 행동을 즐기는 성향이다. } \\
\text { - 겸손한 모습은 사람들에게 온순하고 다정한 모습으로 비춰지며, 다툼을 피하고 협조하는 성향이 있어 대인관계가 원만한 } \\
\text { 성향을 보인다. }\end{array}$ \\
\hline $\begin{array}{l}\text { (4) 신중성 } \\
\text { (prudence) }\end{array}$ & $\begin{array}{l}\text { - 원칙 중싱의 치밀한 성향과 완벽주의와 같은 모습으로 보인다. } \\
\text { - 매사에 철저한 성향은 분석적이고 논리적인 모습으로 나타나며, 사전계획과 같은 체계적인 구조를 즐긴다. } \\
\text { - 목표달성을 위해서 집요하게 파고 들어가는 성향이 있고, 때로는 까다로운 성향을 보이지만, 냉정하고 객관적인 모습을 유 } \\
\text { 지하고자 한다. }\end{array}$ \\
\hline $\begin{array}{l}\text { (5) 안정성 } \\
\text { (stability) }\end{array}$ & $\begin{array}{l}\text { - 차분하고 인내심이 강하고, 쉽게 흥분하거나 즉흥적이지 않다. } \\
\text { - 성급하지는 않지만 부지런하며, 깔끔하게 행동하려는 성향이 있다. } \\
\text { - 눈에 보이지 않는 피상적인 상황보다는 구체적인 것을 좋아하며, 안정되어 있는 모습을 보이는 성향이다. }\end{array}$ \\
\hline
\end{tabular}




\section{III. 연구결과}

\section{1. 일반적 특성}

본 연구 대상자의 인구사회학적 분포에서 남녀 의 분포가 각각 $50 \%$ 전후로 균등하였으며, 대상자 의 절대 다수가 전문대학교 이상의 학력을 가지 고 있었다. 응답자의 평균 나이는 59.7세였으며, 표 준편차는 5.7세였다. 종교의 경우 무교가 $38.5 \%$ 로 가장 많았다<표 2>.

직무와 관련된 특성의 분포에서 응급의료 직무 에 종사한지는 2 3년이 39.7\%로 가장 많았으며, 근무경력은 2 4년 $41.0 \%$ 로 가장 많았다. 보수 수 준은 130 만원에서 159 만원으로 $48.7 \%$, 3교대 근무 형태를 취하고 있는 대상자가 $55.8 \%$ 로 가장 많았 다. 또한 업무강도에서는 5점을 가장 높은 수준으 로 할 때 대상자들은 3점 정도로 평가하였고, 표준 편차는 1.3 이었다<표 $3>$.

<표 2> 인구사회학적 변수의 분포 $(n=156)$

\begin{tabular}{|c|c|c|c|}
\hline 변수 & 수준 & & 도(\%) \\
\hline \multirow[t]{2}{*}{ 성 } & 남 & 79 & $\overline{~(50.6)}$ \\
\hline & 여 & 77 & $(49.4)$ \\
\hline \multirow[t]{2}{*}{ 결혼 } & 미혼 & 124 & $(79.5)$ \\
\hline & 기혼 & 32 & (20.5) \\
\hline \multirow[t]{4}{*}{ 종교 } & 기독교 & 41 & (26.3) \\
\hline & 불교 & 51 & $(32.7)$ \\
\hline & 천주교 & 4 & ( 2.6) \\
\hline & 무교 & 60 & $(38.5)$ \\
\hline \multirow[t]{3}{*}{ 학력 } & 전문대학교 이하 & 112 & $(70.8)$ \\
\hline & 대학교 & 41 & (26.3) \\
\hline & 석사이상 & 3 & ( 1.9) \\
\hline \multirow[t]{5}{*}{ 나이 } & 25세미만 & 12 & $(7.7)$ \\
\hline & 25-29세 & 83 & (53.2) \\
\hline & 30-34세 & 44 & $(28.2)$ \\
\hline & 35-39세 & 8 & $(5.1)$ \\
\hline & 40세이상 & 9 & $(5.8)$ \\
\hline
\end{tabular}

<표 3> 직무특성 변수에 대한 분포 $(n=156)$

\begin{tabular}{|c|c|c|c|}
\hline \multirow{2}{*}{$\begin{array}{c}\text { 변수 } \\
\text { 직무경력 }\end{array}$} & 수준 & \multicolumn{2}{|c|}{ 빈도(\%) } \\
\hline & 2년 미만 & 24 & $\overline{(15.4)}$ \\
\hline & 2-3년 & 62 & (39.7) \\
\hline & 4-5년 & 44 & (28.2) \\
\hline & 6년 이상 & 26 & $(16.7)$ \\
\hline \multirow[t]{5}{*}{ 보수수준 } & 130만원 미만 & 25 & $(16.0)$ \\
\hline & 130-159만원 & 76 & $(48.7)$ \\
\hline & 160-189만원 & 24 & (15.4) \\
\hline & 190-209만원 & 15 & (9.6) \\
\hline & 210만원 이상 & 16 & $(10.3)$ \\
\hline \multirow[t]{5}{*}{ 업무강도 } & 매우 약함 & 21 & (13.5) \\
\hline & 약함 & 38 & (24.4) \\
\hline & 보통 & 38 & (24.4) \\
\hline & 강함 & 37 & (23.7) \\
\hline & 아주 강함 & 22 & $(14.1)$ \\
\hline \multirow[t]{4}{*}{ 근무경력 } & 2년 미만 & 43 & (27.6) \\
\hline & 2-4년 & 64 & $(41.0)$ \\
\hline & 4-6년 & 28 & (18.0) \\
\hline & 6년 이상 & 21 & $(13.5)$ \\
\hline \multirow[t]{5}{*}{ 근무형태 } & 2교대 & 18 & $(11.5)$ \\
\hline & 3교대 & 87 & (55.8) \\
\hline & 격일제 & 5 & ( 3.2$)$ \\
\hline & 주근제 & 35 & (22.4) \\
\hline & 기타 & 11 & ( 7.1$)$ \\
\hline
\end{tabular}

2. 측정도구 신뢰도와 구성 타당도

본 연구 종속변수로 사용된 5가지 변수에 대한 신뢰도와 타당도를 파악하였다. 사회적 스트레스를 측정한 항목에서는 구성타당도가 낮아 제외해야할 항목이 없었다. 조직몰입 항목의 경우 6 개 항목 중 2항목의 신뢰도가 낮아 제외하였으며, 역할갈등은 7 개중 3 개의 항목만이 타당성이 있었다. 직무만족 항목은 5 개중 2 개를 제외했으며, 자기효능감에서는 1 개의 항목이 신뢰도가 낮아 제외하였다. 신뢰도가 확보된 항목만을 사용하여 다시 신뢰도 분석을 한 결과 각 요인의 Cronbach's a 계수가 최소 .76에서 .92 까지 분포하여 높은 신뢰도를 가지고 있었다 <표 4>. 이상에서 제외된 항목만을 이용하여 요인 분석을 한 결과 모든 항목들이 의도한 각자의 요 인에 할당하였다<표 5>. 
<표 4> 직무관련 산출변수에 대한 신뢰도

\begin{tabular}{|c|c|c|c|}
\hline 요인명 & 변수명 & 측정항목 & Cronbach's Alpha \\
\hline 사회적 & "ST1 & 환자나 보호자로부터 욕/폭언을 경험함 & .92 \\
\hline \multirow[t]{4}{*}{ 스트레스 } & ST2 & 환자나 보호자 나를 신뢰하지 않음 & \\
\hline & ST3 & 환자나 보호자 비협조적임 & \\
\hline & ST4 & 환자나 보호자 구타나 밀침을 당함 & \\
\hline & ST5 & 환자나 보호자가 의지하지 않음 & \\
\hline \multirow[t]{4}{*}{ 조직몰입 } & OC2 & 내가 근무하는 조직은 일할 만한 훌륭한 조직임" & .85 \\
\hline & OC3 & 나의 조직에 대한 애착심이 있음 & \\
\hline & OC5 & 나의 가치관과 조직의 가치관이 매우 유사함 & \\
\hline & OC6 & 내 조직은 내가 최선을 다하여 직무성과를 올리도록 격려함 & \\
\hline \multirow[t]{3}{*}{ 역할갈등 } & RC2 & 타부서에 비하여 자율적 권한이 적어 불만 & .89 \\
\hline & RC3 & 타부서와 역할이 중복되거나 모호한 부분에서 마찰 & \\
\hline & $\mathrm{RC} 4$ & 업무 과정에서 타부서의 언행이나 태도 때문에 불쾌감 & \\
\hline \multirow[t]{3}{*}{ 직무만족 } & JS3 & 급여수준에 만족함 & .90 \\
\hline & JS4 & 제공되는 정기건강진단 검시종류나 수준에 만족함 & \\
\hline & JS5 & 현재의 직무관련 교육에 만족함 & \\
\hline \multirow[t]{3}{*}{ 자기효능감 } & SF1 & 목표를 달성할 수 있는 능력을 가지고 있음 & .76 \\
\hline & SF2 & 목표를 달성을 위해 내 행동을 관리/통제할 수 있음 & \\
\hline & SF3 & 목표를 스스로 달성할 수 있도록 나를 훈련시킴 & \\
\hline 직무 & JT1 & 해야 할일이 많기 때문에 피곤함 & .82 \\
\hline 스트레스 & JT3 & 2 또는 3교대 때문에 정신적으로 피곤함 & \\
\hline
\end{tabular}

<표 5> 직무관련 산출 변수에 대한 요인분석

\begin{tabular}{|c|c|c|c|c|c|c|c|}
\hline 요인명 & 변수명a & 요인1 & 요인2 & 요인3 & 요인4 & 요인5 & 요인6 \\
\hline 사회적 스트레스 & $\begin{array}{l}\text { ST1 } \\
\text { ST2 } \\
\text { ST3 } \\
\text { ST4 } \\
\text { ST5 }\end{array}$ & $\begin{array}{l}.81 \\
.84 \\
.86 \\
.82 \\
.70\end{array}$ & & & & & \\
\hline 조직몰입 & $\begin{array}{l}\text { OC2 } \\
\text { OC3 } \\
\text { OC5 } \\
\text { OC6 }\end{array}$ & & $\begin{array}{l}.59 \\
.82 \\
.70 \\
.78\end{array}$ & & & & \\
\hline 역할갈등 & $\begin{array}{l}\mathrm{RC} 2 \\
\mathrm{RC} 3 \\
\mathrm{RC} 4\end{array}$ & & & $\begin{array}{l}.75 \\
.64 \\
.51\end{array}$ & & & \\
\hline 직무만족 & $\begin{array}{l}\text { JS3 } \\
\text { JS4 } \\
\text { JS5 }\end{array}$ & & & & $\begin{array}{l}.52 \\
.79 \\
.76\end{array}$ & & \\
\hline 자기효능감 & $\begin{array}{l}\text { SF1 } \\
\text { SF2 } \\
\text { SF3 }\end{array}$ & & & & & $\begin{array}{l}60 \\
81 \\
83\end{array}$ & \\
\hline 직무스트레스 & $\begin{array}{l}\text { JT1 } \\
\text { JT3 }\end{array}$ & & & & & & $\begin{array}{l}.79 \\
.77\end{array}$ \\
\hline
\end{tabular}

a: 변수명 설명은 <표 4> 참조 
3. 성격과 직무특성이 직무관련 산출변수에 미치는 영향력

성격특성과 직무 관련 변수들이 제시된 6개의 회귀모형에서의 유의성을 파악하였다. 성격유형은 사회적 스트레스모형, 직무만족 모형, 그리고 역할 갈등 모형에서 모두 유의하였다. 사회적 스트레스 모형에서는 안정성 유형보다 다른 모든 성격 유형 이 더 높은 수준의 사회적 스트레스를 경험하였으 며, 직무만족 수준은 안정성 유형보다 도전성, 사 교성, 신중성 유형 모두가 유의하게 낮았다. 역할 갈등에서는 안정성 유형보다 도전성, 수용성, 그리 고 신중성 유형이 유의하게 높은 수준의 역할갈등 을 경험하였다<표 6>.

직무 관련 변수로 회귀모형에 포함된 변수 중 업무강도, 보수, 그리고 근무형태가 적어도 하나의 회귀모형에서 유의하였다. 업무강도의 경우 역할갈 등 회귀모형에서만 유의하였으며, 업무강도가 역할 갈등에 부의 영향력을 가지고 있었다. 보수 수준은 직무만족과 조직몰입에 양의 영향력을 가지는 반 면, 직무스트레스와 역할갈등에는 부의 영향력을 가지고 있었다.

근무형태에서는 2교대 근무를 준거집단으로 하 였을 때 사회적 스트레스 모형, 역할갈등 모형, 그 리고 자기효능감 모형에서 각각 유의하였다. 2교대 근무를 하고 있는 응답자 보다 3 교대를 하고 있는 응답자의 사회적 스트레스와 역할갈등이 각각 유 의하게 더 높았다<표 6>.
4. 회귀모형의 비교

성격특성과 직무 관련 변수들의 영향력을 파악 한 표5의 결과를 바탕으로 두 변수가 동시에 유의 한 모형들에 대하여 부분적 F-검정(partial F-test) 을 이용하여 모형의 우수성을 비교하였다. 사회적 스트레스를 종속변수로 했을 때 모든 변수를 포함 한 완전모형에서 성격 변수와 직무 변수를 각각 제외한 경우 각각 두 모형비교는 통계학적으로 유 의한 차이가 있었다. 이는 성격변수와 직무변수를 동시에 포함한 완전 모형이 더 설명력이 높은 회 귀모형이라 할 수 있다. 이는 직무만족과 역할갈등 에서도 동일한 결과였다.

성격유형과 직무 특성들의 회귀모형에 대한 기 여도를 평가하기 위하여 델타 $\mathrm{R}^{2}$ 를 산출하였다. 사 회적 스트레스에 대한 독립변수들의 설명력에서 성격은 $14 \%$ 의 설명력을 추가하였고 $(\mathrm{p}<.001)$, 직무 변수는 $19 \%$ 의 설명력을 추가 하였다( $p<.001)$. 또한 직무만족에서는 성격유형이 $5 \%$, 직무변수가 $8 \%$, 역학갈등에서는 성격유형이 $4 \%$, 직무변수가 $18 \%$ 의 설명력의 향상에 기여하였고, 표7과 같이 모든 유형에서 통계학적으로 유의하였다. 따라서 성격유 형은 역할갈등 보다 사회적 스트레스에서 상대적 으로 더 큰 영향력을 가지고 있었으며, 역할갈등에 서는 성격유형보다 직무변수의 영향력이 더 많은 비중을 차지하였다. 
<표 6> 성격 및 직무변수의 직무관련 산출변수에 대한 영향력 $(\mathrm{n}=156)$

\begin{tabular}{|c|c|c|c|c|c|c|c|c|c|c|c|c|c|}
\hline & 변수 & & |무 스트르 & 레스 & & & 회적 스트 & 레스 & & & 직무만족 & & \\
\hline & & $\mathrm{PE}$ & ( SE) & $t$ & & $\mathrm{PE}$ & ( SE) & $t$ & & $P E$ & ( SE) & $t$ & \\
\hline 성격유형a & 도전성 & .15 & (.51) & .29 & & 5.84 & (1.07) & 5.45 & **** & -2.03 & (.79) & -2.57 & * \\
\hline & 사교성 & .76 & (.85) & .90 & & 4.81 & $(1.80)$ & 2.67 & $\star * *$ & -3.17 & (1.33) & -2.39 & * \\
\hline & 수용성 & .60 & (.47) & 1.27 & & 5.68 & $(1.00)$ & 5.70 & $* * *$ & -1.35 & (.74) & -1.84 & \\
\hline & 신중성 & .48 & $(.51)$ & .95 & & 4.72 & $(1.08)$ & 4.37 & $* * *$ & -2.30 & $(80)$ & -2.89 & $\star *$ \\
\hline 직무변수 & 업무강도 & -.02 & $(.11)$ & -.17 & & -.28 & $(.22)$ & -1.26 & & .22 & $(.16)$ & 1.35 & \\
\hline & 직종경력 & .01 & $(.01)$ & 1.97 & & .00 & $(.01)$ & -.33 & & -.02 & $(.01)$ & -2.18 & \\
\hline & 근무경력 & .00 & $(.00)$ & -.99 & & -.01 & $(.01)$ & -.80 & & .00 & $(.01)$ & -.43 & \\
\hline & 보수 & -.01 & $(.00)$ & -2.18 & * & -.02 & $(.01)$ & -1.87 & & .02 & $(.01)$ & 3.64 & * \\
\hline & 3교대근무b & .47 & (.41) & 1.14 & & 2.50 & (.86) & 2.89 & $\star *$ & .13 & (.64) & .21 & \\
\hline & 격일제근무b & -.21 & $(.77)$ & -.28 & & 1.57 & (1.62) & .97 & & .39 & (1.19) & .32 & \\
\hline & 주근제근무b & .04 & (.45) & .10 & & 1.62 & (.95) & 1.71 & & .76 & ( . .70) & 1.08 & \\
\hline & 기태애 & .13 & $(.58)$ & .23 & & -2.70 & $(1.22)$ & -2.22 & * & 96 & $(.90)$ & 1.08 & \\
\hline 인구사회학적 & 남c & -.23 & $(.28)$ & -.83 & & -.11 & $(.58)$ & -.19 & & -.40 & $(.43)$ & -.94 & \\
\hline 변수 & 결혼d & -.28 & (.37) & -.77 & & -.01 & $(.78)$ & -.01 & & 1.46 & $(.57)$ & 2.55 & * \\
\hline & 대졸이상e & -.54 & $(.30)$ & -1.80 & & .28 & (.63) & .44 & & .51 & $(.46)$ & 1.10 & \\
\hline & 기독교f & .35 & (.36) & .99 & & 1.40 & $(.75)$ & 1.86 & & 2.51 & $(.56)$ & 4.52 & $\star * *$ \\
\hline & 불교f & -.17 & $(.31)$ & -.54 & & .77 & $(.66)$ & 1.17 & & 1.71 & $(.49)$ & 3.51 & $\star * *$ \\
\hline & 천주교f & -.20 & $(.84)$ & -.24 & & .60 & $(1.78)$ & .34 & & 1.51 & $(1.31)$ & 1.15 & \\
\hline & 절편 & 2.92 & $(.80)$ & 3.63 & $\star * \star$ & 3.77 & $(1.70)$ & 2.22 & * & -5.38 & $(1.25)$ & -4.30 & $\star * *$ \\
\hline & $\mathrm{R}^{2}$ & & $=.29$ & & & & $=.46$ & & & & $=.47$ & & \\
\hline & Adust-R ${ }^{2}$ & & $=.19$ & & & & $=.39$ & & & & $=.42$ & & \\
\hline & $\mathrm{F}$ & & $=3.08 *$ & & & & $=6.53 *$ & & & & $=6.78 * * *$ & & \\
\hline & 변수 & & 역할갈 & & & & 조직돌 & & & & 자기효능 & & \\
\hline & & $\mathrm{PE}$ & (SE) & $\mathrm{t}$ & & $\mathrm{PE}$ & (SE & $t$ & & $\mathrm{PE}$ & (SE) & $\mathrm{t}$ & \\
\hline 성격유형a & 도전성 & 3.16 & $(.88)$ & 3.60 & $\star * \star *$ & -1.24 & $(1.03)$ & -1.20 & & .33 & $(.42)$ & .77 & \\
\hline & 사교성 & 2.37 & $(1.47)$ & 1.61 & & 2.02 & (1.73) & 1.17 & & -.36 & $(.71)$ & -.51 & \\
\hline & 수용성 & 2.57 & (.82) & 3.15 & $\star \star$ & -.14 & (.96) & -.14 & & 16 & ( . .39) & .42 & \\
\hline & 신중성 & 3.44 & $(.88)$ & 3.90 & $\star * *$ & -1.55 & $(1.04)$ & -1.49 & & -.05 & $(.43)$ & -.11 & \\
\hline 직무변수 & 업무강도 & -.45 & $(.18)$ & -2.45 & * & .25 & $(.21)$ & 1.19 & & .05 & $(.09)$ & .54 & \\
\hline & 직종경력 & .01 & $(.01)$ & 1.00 & & -.01 & $(.01)$ & -.50 & & .00 & $(.00)$ & -.42 & \\
\hline & 근무경력 & .01 & $(.01)$ & 1.23 & & -.01 & $(.01)$ & -.87 & & .00 & $(.00)$ & .80 & \\
\hline & 보수 & -.04 & $(.01)$ & -5.33 & $* * *$ & .03 & $(.01)$ & 3.38 & ** & .01 & $(.00)$ & 1.59 & \\
\hline & 3교대근무b & 2.16 & $(.71)$ & 3.06 & $\star \star$ & -1.59 & (.83) & -1.92 & & -.07 & $(.34)$ & -.19 & \\
\hline & 격일제근무b & -.37 & $(1.32)$ & -.28 & & -1.18 & (1.56) & -.76 & & -1.94 & $(.64)$ & -3.04 & ** \\
\hline & 주근제근무b & 1.12 & $(.78)$ & 1.44 & & -.14 & (.91) & -.15 & & -.08 & $(.37)$ & -.21 & \\
\hline & 기태b & -1.25 & $(.99)$ & -1.26 & & -.31 & $(1.17)$ & -.27 & & -.07 & $(.48)$ & -.15 & \\
\hline 인구사회학적 & 남c & .88 & $(.48)$ & 1.84 & & -.31 & (.56) & -.55 & & .08 & $(.23)$ & .36 & \\
\hline 변수 & 결혼d & -1.64 & $(.64)$ & -2.58 & * & .71 & (.75) & .94 & & -.93 & $(.64)$ & -3.01 & ** \\
\hline & 대졸이상e & -.67 & $(.51)$ & -1.31 & & 1.15 & (.60) & 1.91 & & .25 & $(.25)$ & 1.00 & \\
\hline & 기독교f & -.32 & $(.62)$ & -.52 & & 3.47 & (.72) & 4.79 & $\star \star *$ & 1.17 & $(.30)$ & 3.95 & $\star \star *$ \\
\hline & 불교f & -1.88 & $(.54)$ & -3.48 & $* * *$ & 2.40 & (.64) & 3.77 & ** & -.01 & $(.26)$ & -.05 & \\
\hline & 천주교f & -.98 & $(1.46)$ & -.67 & & 2.67 & $(1.71)$ & 1.21 & & 60 & $(.70)$ & .86 & \\
\hline & 절편 & 7.11 & $(1.39)$ & 5.12 & $* * *$ & -5.63 & $(1.62)$ & -2.69 & $\star \star \star$ & .91 & $(.67)$ & 1.36 & * \\
\hline & $\mathrm{R}^{2}$ & & $=.64$ & & & & $=.48$ & & & & $=.28$ & & \\
\hline & Adust- $\mathrm{R}^{2}$ & & $=.60$ & & & & $=.41$ & & & & $=.19$ & & \\
\hline & $\mathrm{F}$ & & $=13.68$ & $3 * * *$ & & & $=7.0$ & $4 * * *$ & & & $=4.05$ & & \\
\hline
\end{tabular}

$\star: p<.05, * \star: p<.01, * \star *: p<.001$

$\mathrm{PE}$ : 추정치, $\mathrm{SE}$ 표준편차

준거집단: $a=$ 안정성,$b=2$ 교대 근무, $c=$ 여, $d=$ 미혼, $e=$ 전문대이하, $f=$ 무교 및 기타 
<표 7> 회귀모형비교 $(n=156)$

\begin{tabular}{|c|c|c|c|c|c|c|c|c|c|c|}
\hline 종속 변수 & 근거모형 & 비교모형 & $\begin{array}{l}\text { 근거모형 } \\
\text { 제곱합 }\end{array}$ & $\begin{array}{c}\text { 비교모형 } \\
\text { 제곱합 }\end{array}$ & $\begin{array}{c}\text { 근거모형 } \\
\text { 잔차 } \\
\text { 평균제곱 }\end{array}$ & k & $\mathrm{F}$ & $\begin{array}{r}\text { 근거 } \\
\text { 모형 } \\
\mathrm{R}^{2} \\
\end{array}$ & $\begin{array}{r}\text { 비교 } \\
\text { 모형 } \\
\mathrm{R}^{2} \\
\end{array}$ & $\begin{array}{c}\text { 델타 } \\
\mathrm{R}^{2}\end{array}$ \\
\hline \multirow{4}{*}{$\begin{array}{l}\text { 사회적 } \\
\text { 스트레스 }\end{array}$} & 직무, 성격, 통제 & 직무, 통제 & 1017.3 & 714.5 & 8.7 & 4 & $8.8 * * *$ & .46 & .32 & 1.14 \\
\hline & 직무,성격,통제 & 성격, 통제 & 1017.3 & 608.6 & 8.7 & 8 & $5.9 * * *$ & .46 & .28 & .19 \\
\hline & 직무, 통제 & 통제 & 714.5 & 307.3 & 11.0 & 8 & $4.6 * * *$ & .32 & .14 & .18 \\
\hline & 성격, 통제 & 통제 & 608.6 & 307.3 & 10.6 & 4 & $7.1 * * *$ & .28 & .14 & .14 \\
\hline \multirow[t]{4}{*}{ 직무만족 } & 직무,성격,통제 & 직무, 통제 & 574.3 & 517.5 & 4.7 & 4 & $3.0 *$ & .47 & .42 & .05 \\
\hline & 직무,성격, 통제 & 성격, 통제 & 574.3 & 482.1 & 4.7 & 8 & $2.5 *$ & .47 & .40 & .08 \\
\hline & 직무, 통제 & 통제 & 517.5 & 423.9 & 5.1 & 8 & $2.3 *$ & .42 & .35 & .08 \\
\hline & 성격, 통제 & 통제 & 482.1 & 423.9 & 5.0 & 4 & $2.9 *$ & .40 & .35 & .05 \\
\hline \multirow[t]{4}{*}{ 역할갈등 } & 직무, 성격, 통제 & 직무, 통제 & 1423.3 & 1325.6 & 5.8 & 4 & $4.2 * \star$ & .64 & .60 & .04 \\
\hline & 직무, 성격, 통제 & 성격, 통제 & 1423.3 & 1016.1 & 5.8 & 8 & $8.8 * * *$ & .64 & .46 & .18 \\
\hline & 직무, 통제 & 통제a & 517.5 & 423.9 & 5.1 & 8 & $2.3 *$ & .60 & .40 & .20 \\
\hline & 성격, 통제 & 통제 & 482.1 & 423.9 & 5.0 & 4 & $2.9 *$ & .46 & .40 & .06 \\
\hline
\end{tabular}

$\star: p<.05, * *: p<.01, * * *: p<.001$

$\mathrm{F}=($ 근거모형 제곱합 - 비교모형 제곱합 $) / \mathrm{k}$

근거모형의 잔차평균제곱

$\mathrm{k}$ : 근거모형과 비교모형의 변수 개수의 차이

델타 $R^{2}=$ 근거모형 $R^{2}-$ 비교모형 $R^{2}$

a: 인구사회학적 변수

\section{IV. 결론 및 고찰}

본 연구는 의료기관에서 응급구조사들의 성격유 형과 업무적 특성이 스트레스, 직무만족, 역할갈등, 조직몰입, 그리고 자기효능감에 미치는 영향을 파 악하고자 하였다. 또한 스트레스를 직무와 관련된 것과 사회적인 측면으로 분리하여 고려하였다. 연 구 대상자는 부산 경남, 경북지역의 종합병원에서 응급구조 담당자를 대상으로 하였다.

성격유형은 사회적 스트레스, 직무만족과 역할 갈등에 유의한 영향력을 가지고 있었으며, 직무변 수 중 보수수준과 근무형태가 각 종속변수에 유의 한 영향력을 가지고 있었다. 또한 성격유형과 직무
변수의 회귀모형에 대한 기여도를 비교한 결과 성 격유형은 사회적 스트레스 모형에서 비교모형에 비해 결정계수가 $14 \%$ 증가하였다. 또한 직무변수 는 사회적 스트레스와 역할갈등에서 결정계수를 각각 $19 \%$ 와 $18 \%$ 만큼 유의하게 증가하였다.

성격유형의 직무스트레스에 대한 영향력은 한경 애 등[20]과 임숙빈과 김경의[21]의 연구와 동일한 결과였다. 두 연구의 경우 간호사를 대상으로 하여 성격유형이 직무 스트레스와 유의한 차이가 없었 다는 결론에 도달하였지만, 이 연구는 응급구조상 의 성격유형이 직무 스트레스에 유의한 영향력이 없었다. 그러나 성격유형이 사회적 스트레스에 미 치는 영향력에서는 응급구조에 근무하는 응답자의 성격유형에 따라 사회적 스트레스에 유의의 차가 있었다. 이는 안정성유형 보다 다른 네 가지 성격 
유형일 경우 더 높은 수준의 사회적 스트레스를 경험하고 있다는 것이다. 보건의료분야에서 이 두 변수의 관계를 규명한 연구가 없어 단순한 비교는 어렵지만, 청소년을 대상으로 한 김성경[22]의 연 구결과를 보면 일상생활의 스트레스가 심리사회적 적응에 유의한 영향이 있음을 고려할 때 조직적 차원에서 응급구조사의 사회적 스트레스를 경감 및 극복을 도울 수 있는 교육 및 훈련이 요구된다 고 할 수 있다.

직무만족에 대한 영향력에서 이 연구에서는 성 격유형과 직무변수 중 보수가 유의한 영향력이 있 었다. 동일한 결과로 여성공무원을 대상으로 한 이 영균[4] 연구와 관리직을 대상으로 연구한 이정선 과 유정이[5]의 연구가 성격유형에 따른 직무 만족 의 차이를 파악하였다. 그러나 양수 외[23] 연구에 서는 성격유형별 직무만족에 유의성을 발견하지 못하였다. 문헌고찰을 통해 파악한 연구들[4][5][23] 은 모두 $\mathrm{t}$-검정과 분산분석을 이용하여 다른 인구 사회학적 요인을 고려하지 못한 단점이 있었지만, 이 연구에서는 회귀분석을 이용하여 인구사회학적 변인을 통제한 상태에서 성격유형이 직무만족에 미치는 고유한 영향을 파악하였다. 또한 직무변수 중 이 연구에서 유의한 변수인 직무보수와 직무 만족의 관계에서는 간호사를 대상으로 연구한 오 명옥 외[24]의 연구와 일치하였다.

역할갈등에 대한 성격과 직무변수의 영향력에서 성격변수에 대한 연구가 미비하였지만, 이 연구에 서는 성격유형이 역할갈등에 영향에 유의한 영향 을 미치고, 안정성 유형보다 다른 모든 유형이 역 할 갈등 수준이 유의하게 높다는 것을 파악하였다. 또한 직무 변수에서는 보수수준과 근무형태에서, 인구사회학적 변수에서는 결혼 상태와 종교가 유 의하였다. 간호사를 대상으로 연구한 성미혜[9]의 연구에서도 경력, 종교, 결혼상태가 역할갈등과 유 의한 영향력이 있었다. 만약 경력이 보수수준에 상 당한 관련성이 있다고 가정할 수 있다면 이 연구
와 매우 유사한 결과로 해석할 수도 있다.

결론적으로 이 연구에서 제시한 성격 유형과 직 무 관련변수가 병원에서 일하는 응급구조사의 사 회적 스트레스, 직무만족, 역할 갈등에 유의한 영 향력이 있으며, 조직몰입과 자기효능감은 직무 변 수에 따른 유의성을 파악하였다. 이 연구의 함의는 응급구조사의 업무를 수행하는 것에 있어 이 직무 와 가장 잘 맞을 수 있는 성격유형을 파악할 수 있다면, 보다 효과적이고 효율적인 인력관리가 가 능할 것이라는 전제에서 출발하였다. 따라서 이 연 구에서는 응급구조사로서 갖추어야할 성격 유형은 차분하고 인내심이 강하며 흥분하지 않으며, 성급 하지 않고, 피상적인 것 보다 구체적인 것을 좋아 하는 성향을 가진 안정성의 성격을 소유한 인력이 라 할 수 있다. 그러나 현실에서 모든 응급구조사 가 이러한 성격만을 가진 사람으로 구성할 수 없 다는 한계가 있으므로, 각 병원에서는 이러한 특성 을 함양 및 배양할 수 있는 교육훈련 프로그램을 운영하거나, 팀을 이루어 일할 경우 반드시 안정성 유형과 타 유형 인력을 짝으로 배치하여 자신의 성격 유형 때문에 발생할 수 있는 어려움을 동료 토론 및 교감을 통해 극복할 수 있는 전략 등을 생각해 볼 수 있다. 이 연구의 한계로는 영남지역 만을 연구대상으로 하였다는 것과 병원의 특성에 따른 층화표출을 실시할 수 있었다면 연구 결과의 일반화에 더 높은 신뢰성을 확보할 수 있었을 것 으로 생각된다.

\section{참고문헌}

1. 보건복지부, 국립의료원, 중앙응급의료센타(2007), 응급의료체계, pp.6-7; 22-27.

2. 강병우 외 16 인(2007), 응급의료관련법령, 현문사, p.113.

3. 보건복지부, 중앙응급으료센터, 영남대학교 산학협 
력단(2007), 병원 전 응급의료에 관한 교재개발 배 포, p.50.

4. 이영균, 최인숙(2011), 여성공무원의 성격유형 (MBTI)와 직무만족도의 관계분석, 한국정책연구, Vol.11(1);1-21.

5. 이정선, 유정이(2002), 관리직 종사자의 성격유형 과 직무만족요인과의 관계 연구, 한국심리유형학 회지, Vol.9(-);31-48.

6. 조희, 강윤숙, 이옥철, 전시자, 이승한, 윤정금 (1999), 소방대원의 스트레스 정신건강에 관한 연 구, 적십자간호대한논문집, Vol.23(1);113-125.

7. 황규대 외 3인 (2007), 조직행동의 이해, 박영사, p.514.

8. G.R. Pierce, I.G. Sarason(1996), Conceptualizing and assessing social support in the context of the family, G.R., Pierce, Sarason, B. R., \& Sarason, I. G.(Ed), Handbook of Support and the Family, New York: Pleum Press, pp.3-24.

9. 성미혜(2006), 중환자실 간호사와 일반병동 간호사 의 역할갈등과 직무만족도 비교연구 중환자실 간 호사와 일반병동 간호사의 역할갈등과 직무만족 도 비교연구, 간호행정학회지, Vol.12(1);101-112.

10. 박상섭, 박재성, 박대성(2009), 병원 내 응급구조 사의 직무만족도가 조직몰입에 미치는 영향, 한국 응급구조학회논문지, Vol.13(2);99-108.

11. 박재산, 이미순, 종합병원의 간호조직문화가 간호 사의 직무만족과 이직의사에 미치는 영향, 보건의 료산업학회지, Vol.5(3);1-11.

12. 여진동, 고인호, 방사선사의 직무만족과 이직의도 와의 관계, 보건의료산업학회지, Vol.4(1);111-123.

13. 박제일, 이정현, 임승환(2005), ITS(Interpersonal Trait Scale)검사의 타당화 연구, 한국동서정신과학 회지, Vol.8(2);165-181.

14. 김매자, 구미옥(1984), 간호사가 근무 중에 경험 하는 스트레스 측정을 위한 도구 개발 연구, 대한 간호학회지, Vol.14(2);28-37.

15. 김성곤(2002), 소방공무원의 직무스트레스에 관한 연구, 단국대학교 정책경영대학원 석사논문, p.45.
16. R.J. House and J.R. Rizzo(1992), Role conflict and ambiguity as critical variables in model of organizational behaviors, OBHP, pp.345-348.

17. 김영훈(2001), 병원종사자의 구직구조 및 조직문 화 인식과 조직갈등 경험, 조직몰입간의 관계, 연 세대학교 대학원 박사학위 논문, pp.57-58.

18. 서흥수(2002), 119 구급대원의 직무스트레스가 조 직몰입과 소진에 미치는 영향에 관한 연구, 동국 대학교 사회과학대학원 사회복지 석사논문, pp.29-30.

19. 박재성(2007), 한 종합병원 구성원의 경영목표 지 향성의 구조적 모형과 선호 경영성과지표, 보건행 정학회지, Vol.17(1);50-74.

20. 한애경, 김옥수, 원종순(2007), 임상간호사의 성격 유형에 따른 직무 스트레스와 대응방법에 관한 연구, 임상간호연구, Vol.13(2);125-136.

21. 임숙빈, 김경의(2005), 간호사의 성격유형에 따른 직무 스트레스와 대처 방식, 정신간호학회지, Vol.14(4);390-399.

22. 김성경(2003), 그룹홈 청소년의 일상생활 스트레 스가 심리사회적 적응에 미치는 영향연구, Vol.10(1);117-137.

23. 양수, 양남영, 차정희(2004), 간호사의 에니어그램 성격유형별 간호전문직 태도와 직무만족 간호사 의 에니어그램 성격유형별 간호전문직 태도와 직 무만족, 간호행정학회지, Vol.10(3);299-308.

24. 오명옥, 성미혜, 김양원(2011), 응급실 간호사의 직무 스트레스, 피로, 직무 만족 및 조직몰입, 임 상간호연구, Vol.17(2);215-227.

접수일자 2012년 6월 29일 심사일자 2012년 8월 1일 게재확정일자 2012년 8월 14일 